\title{
Imaging of metabolism and autonomic innervation of the heart by positron emission tomography *
}

\author{
Pierre Mélon and Markus Schwaiger \\ Division of Nuclear Medicine, Department of Internal Medicine, University of Michigan Medical Center, \\ 1500 E. Medical Center Drive, UH BIG412 Ann Arbor, MI 48109-0028, USA
}

\begin{abstract}
Positron emịssion tomography (PET) allows, in combination with multiple radiopharmaceuticals, unique physiological and biochemical tissue characterization. Tracers of blood flow, metabolism and neuronal function have been employed with this technique for research application. More recently, PET has emerged in cardiology as a useful tool for the detection of coronary artery disease and the evaluation of tissue viability. Metabolic tracers such as fluorine-18 deoxyglucose (FDG) permit the specific delineation of ischaemically compromised myocardium. Clinical studies have indicated that the metabolic imaging is helpful in selecting patients for coronary artery bypass surgery or coronary angioplasty. More recent research work has concentrated on the use of carbon-11 acetate as a marker of myocardial oxygen consumption. Together with measurements of left ventricular performance, estimates of cardiac efficiency can be derived from dynamic ${ }^{11} \mathrm{C}$-acetate studies. The non-invasive evaluation of the autonomic nervous system of the heart was limited in the past. With the introduction of radiopharmaceuticals which specifically bind to neuronal structures, the regional integrity of the autonomic nervous system of the heart can be evaluated with PET. Numerous tracers for pre- and postsynaptic binding sites have been synthesized. ${ }^{11} \mathrm{C}$-hydroxyephedrine represents a new catecholamine analogue which is stored in cardiac presynaptic sympathetic nerve terminals. Initial clinical studies with it suggest a promising role for PET in the study of the sympathetic nervous system in various cardiac diseases such as cardiomyopathy, ischaemic heart disease and diabetes mellitus. The specificity of the radiopharmaceuticals and the quantitative measurements of tissue tracer distribution provided by PET make this technology a very attractive research tool in the cardiovascular sciences with great promise in the area of cardiac metabolism and neurocardiology.
\end{abstract}

\footnotetext{
* This work was supported by National Institutes of Health grant R01 HL41047-02 and the American Heart Association of Michigan grant 88-0699.

Dr. Pierre Mélon is a research fellow supported by the National Foundation for Scientific Research of Belgium and in part by a grant of the Belgian Leon Fredericq Foundation.
}

Offprint requests to: $\mathrm{M}$. Schwaiger
Key words: Positron emission tomography - Cardiac metabolism - Cardiac autonomic innervation

Eur J Nucl Med (1992) 19:453-464

\section{Introduction}

Cardiac imaging has developed rapidly over the past 20 years. Scintigraphic techniques excel in the evaluation of blood flow and left ventricular function. With the introduction of positron emission tomography (PET), numerous physiological and biochemical tissue functions can be assessed with specific radiopharmaceuticals tracing metabolism or neuronal function.

The contractile and electrophysiological properties of the heart are dependent on the underlying cellular metabolism. Measurements of substrate utilization by the heart were first possible after the introduction of coronary sinus catheterization by Bing in 1947 (Bing 1954). This invasive technique, relying on the measurement of the arteriovenous differences of substrate concentrations, was used to assess the metabolism of the heart globally. However, regional differences in cardiac metabolism are expected in ischaemic heart disease, which cannot be assessed by metabolic measurements based on arteriovenous sampling. With the recent introduction of metabolic tracer techniques in combination with single photon emission tomography (SPET) and PET, the noninvasive assessment of the regional biochemistry of the heart has become possible. Similarly, radiopharmaceuticals tracing the sympathetic and parasympathetic nervous system have been synthesized which allow us, for the first time, to non-invasively evaluate the regional integrity of cardiac innervation.

This review will focus on PET technology and its application for the study of cardiac metabolism and autonomic nervous function. The clinical application of this technique as well as its use as a sophisticated research tool will be discussed.

Among human organs, the heart has one of the highest energy demands per gram of tissue. The oxygen re- 


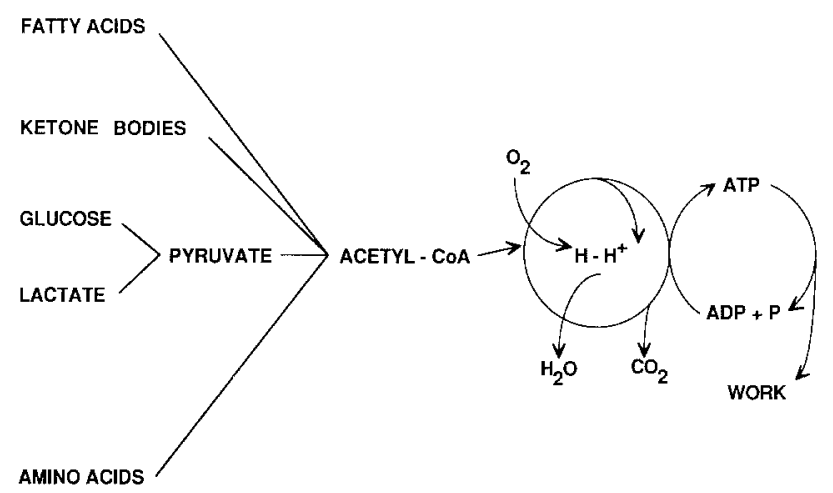

Fig. 1. Substrates contributing to the myocardial energy metabolism. Acetyl-coenzyme A ( $\mathrm{CoA})$ represents the final product of various pathways entering the tricarboxylic acid cycle and provides ATP generation

quirements of the heart average 6-8 $\mathrm{ml}$ per minute per $100 \mathrm{~g}$ at rest compared with only $0.15 \mathrm{ml}$ per min per $100 \mathrm{~g}$ for resting skeletal muscle. Approximately $80 \%$ of the myocardial oxygen consumption is related to mechanical work, with only $20 \%$ used to maintain cellular integrity. In line with this high energy demand, the extraction of oxygen by myocardial tissue is high and can only be slightly increased in response to an increased oxygen demand. Therefore, the myocardial blood flow must be closely matched to the energy demand in the normal heart. The heart displays a remarkable ability to metabolize a large variety of energy-providing substrates. Depending on the plasma substrate level, hormonal factors, and myocardial oxygen supply and demand, the heart preferentially selects free fatty acids, glucose, lactate, pyruvate, ketone bodies or amino acids (Bing 1965; Liedtke 1981; Neely and Morgan 1974; Opie et al. 1975). Under fasting conditions, the normal heart produces as much as $70 \%$ of its energy by free fatty acid oxidation (Bing 1965; Neely and Morgan 1974). Glucose oxidation accounts for the remaining $30 \%$ of energy production. Following carbohydrate loading, plasma insulin and glucose levels increase while the free fatty acid levels decrease. Under these circumstances, the heart primarily metabolizes glucose. During exercise, lactate production provides an important alternate energy source for cardiac metabolism (Liedtke 1981). In the myocyte, each energy-providing substrate enters its specific metabolic pathway and finally contributes to acetylcoenzyme A (CoA) production (Fig. 1). Acetyl-CoA then enters the tricarboxylic acid cycle. High energy phosphates, or ATP, represent the final product of substrate metabolism, and their subsequent hydrolysis maintains cardiac performance. During ischaemia, betaoxidation of free fatty acids, which is very sensitive to the oxygen supply, is rapidly impaired (Liedtke 1981; Opie et al. 1975). The production of energy during ischaemia depends principally on accelerated glycogen breakdown and increased glycolytic flux (Liedtke 1981). However, in very low flow ischaemia, glycolysis may cease through the accumulation of metabolites such as lactate, produced by the non-oxidative utilization of glucose (Opie et al. 1975). As high energy phosphate production primarily depends on aerobic cellular metabolism, a decrease of the oxygen supply leads to insufficient ATP synthesis to maintain myocyte contraction. The transient energy supply by anaerobic metabolism during ischaemia may, however, be beneficial for preserving the integrity of the cell membrane and, hence, cell survival.

\section{Positron emission tomography}

PET relies on the detection of a coincidence of photons from positron annihilation using aligned detectors. By the association of multiple paired detectors, most stateof-the-art tomographs currently allow the simultaneous definition of the tracer spatial distribution of the entire heart. Image correction for tissue attenuation allows for regional quantification of the tracer distribution. The current spatial resolution provided by PET (range between 5 and $10 \mathrm{~mm}$ ) does not compete with that for echocardiography and magnetic resonance spectroscopy. However, PET excells by its sensitivity which allows the detection of low tissue concentrations of radioactivity. This ability minimizes the patient's exposure to radiation and the pharmacological effects of most of the radiopharmaceuticals. The commonly used positron emitters include oxygen-15, carbon-11, nitrogen-13 and fluorine-18, which can be implemented in a variety of biologically active compounds without affecting their physiological behaviour. Thus, PET benefits from a virtually unlimited number of tracers to explore specific myocardial functions. Furthermore, the short half-lives of positron emitters allow rapid sequential studies of cardiac metabolism in response to changing workload conditions, substrate availability or oxygen supply; however, this also demands the presence of an on-site cyclotron for their production and sophisticated radiochemical technologies for their incorporation into the substrate.

\section{Metabolic PET tracers}

The development of metabolic tracers concentrated initially on fatty acids and glucose metabolism (Fig. 2). The most widely employed radiopharmaceuticals are ${ }^{11} \mathrm{C}$-palmitate, ${ }^{11} \mathrm{C}$-acetate and ${ }^{18} \mathrm{~F}$-deoxyglucose, which will be discussed.

The fatty acid ${ }^{11} \mathrm{C}$-palmitate has been introduced to characterize the metabolism of fatty acids in the myocardium (Bergmann 1989; Schelbert et al. 1983 a, b; Schön et al. 1982; Sobel et al. 1977). Avidly extracted by the myocardium, the initial uptake of ${ }^{11} \mathrm{C}$-palmitate primarily represents blood flow. The ${ }^{11} \mathrm{C}$-palmitate activity then clears from the myocardium according to a biexponential pattern. The early rapid clearance phase re- 


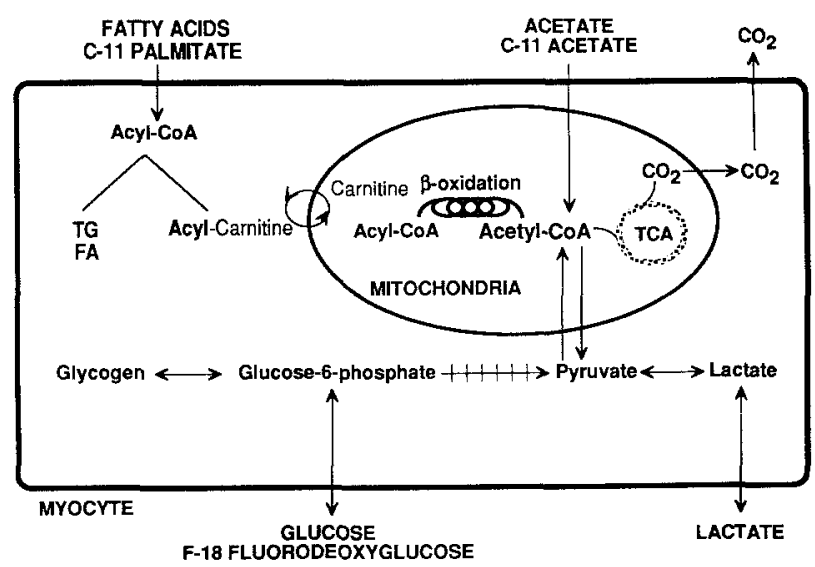

Fig. 2. Metabolic pathways of myocardial substrate metabolism: carbon-11 palmitate and fluorine-18 fluorodeoxyglucose $\left({ }^{18} \mathrm{~F}\right.$ FDG) trace the metabolic fate of free fatty acids and glucose, respectively. ${ }^{11} \mathrm{C}$-acetate enters the tricarboxylic acid cycle $(T C A)$ and gives an estimation of the cardiac oxidative metabolism independent of overall substrate utilization. $T G$, triglycerides; $F A$, fatty acids

flects the fatty acid beta-oxidation, while the slow clearance represents incorporation of the tracer in the lipid pool (Schön et al. 1982). Under different experimental conditions, the size and the rate of the early clearance correlated well with changes in cardiac workload and substrate utilization (Schelbert et al. 1983b). ${ }^{11} \mathrm{C}$-palmitate PET studies have contributed to a better understanding of fatty acid metabolism. However, the contamination of the early clearance phase by back-diffusion of unmetabolized tracer (Fox et al. 1985) and the complexity of fatty acid metabolism have limited the tracer modeling and its clinical application.

Also avidly extracted by the myocardium, the initial uptake of ${ }^{11} \mathrm{C}$-acetate reflects tracer delivery and, thus, myocardial blood flow. Within the myocyte, ${ }^{11} \mathrm{C}$-acetate is rapidly activated to acetyl-CoA, which enters the tricarboxylic acid cycle. The ${ }^{11} \mathrm{C}$ activity equilibrates in the pool of tricarboxylic acid cycle intermediates (Lear 1986) and clears in the form of ${ }^{11} \mathrm{CO}_{2}$ from the myocardium as a function of the tricarboxylic acid cycle activity. Since the tricarboxylic cycle represents the final common metabolic pathway of oxidative metabolism, ${ }^{11} \mathrm{C}$-acetate can be used to assess cardiac metabolism independent of overall substrate utilization (Buxton et al. 1988). Several animal studies have demonstrated a close relationship between the ${ }^{11} \mathrm{C}$ clearance rate and myocardial oxygen consumption over a wide range of physiological conditions (Brown et al. 1987, 1989; Buxton et al. 1988). Comparison of ${ }^{11} \mathrm{C}$-acetate clearance rate with indirect measures of oxygen consumption (i.e. pressure-rate product) has confirmed this relationship in human studies (Armbrecht et al. 1989; Henes et al. 1989). Using a mono- or biexponential curve-fitting approach of PETderived ${ }^{11} \mathrm{C}$ clearance patterns from the myocardium, it is possible to characterize myocardial oxidative metabolism quantitatively (Armbrecht et al. 1989; Brown et al.
1987, 1988, 1989; Buxton et al. 1988, 1989). However, quantitative assessment of ${ }^{11} \mathrm{C}$-acetate kinetics requires the correction of ${ }^{11} \mathrm{C}$-acetate input function for ${ }^{11} \mathrm{C}$ metabolite contamination. Recently, Buck et al. (1991) demonstrated that the metabolite correction can be performed by a mathematical model. Thus, PET provides an non-invasive approach for the quantitative assessment of myocardial oxygen consumption.

${ }^{18} \mathrm{~F}$-Deoxyglucose $\left({ }^{18} \mathrm{~F}\right.$-FDG) traces the utilization of exogenous glucose by the myocardium. It competes with glucose for transmembranous transport and phosphorylation by the hexokinase reaction to FDG-6-phosphate. The phosphorylated product is not further metabolized and does not participate in glycogen synthesis, glycolysis or the pentose phosphate shunt pathway (Gallagher et al. 1978; Phelps et al. 1979).

${ }^{18}$ F-FDG kinetics derived from dynamic PET imaging have been successfully employed to quantify the rate of exogenous myocardial glucose utilization (Gambhir et al. 1989; Ratib et al. 1982). Although ${ }^{18}$ F-FDG is an analogue of glucose, its affinity for transport and phosphorylation differs. A function termed "lumped constant" corrects for this difference in the three-compartmental model introduced by Sokoloff (Huang et al. 1987; Sokoloff et al. 1977). Experimental studies have demonstrated the stability of this constant under various physiological conditions (Marshall et al. 1983a). FDG has been proven to provide a qualitative and quantitative evaluation of cardiac exogeneous glucose utilization.

\section{Clinical application of metabolic PET imaging}

The combined use of metabolic tracers and PET offers a unique approach to characterize non-invasively the metabolism of the myocardium (Fig. 3). However, an in-depth understanding of tracer distribution in the normal myocardium is required to correctly assess the changes of tracer distribution observed in cardiac diseases. This point has become of great importance since recent studies have described inhomogeneous ${ }^{18}$ F-FDG distribution in the normal heart. Under fasting conditions, Gropler et al. (1990) have demonstrated that ${ }^{18} \mathrm{~F}$ FDG uptake was decreased in the septum as compared with that in the lateral wall. Using hyperinsulinaemiceuglycaemic clamping with and without lipid infusion, Hicks et al. (1991) have also reported similar inhomogeneity of regional glucose metabolism, though less marked than under fasting conditions. As in both studies ${ }^{11} \mathrm{C}$-acetate clearance was maintained unchanged in the septum, decreased septal oxidative metabolism is excluded as an explanation for this regionally decreased uptake of ${ }^{18}$ F-FDG. This interesting finding may reflect regional variability in the substrate selection. However, regional variation of the lumped constant or the dephosphorylation rate of FDG-6-phosphate may also contribute to the inhomogeneity of cardiac FDG uptake. This hypothesis awaits further experimental evaluation. 


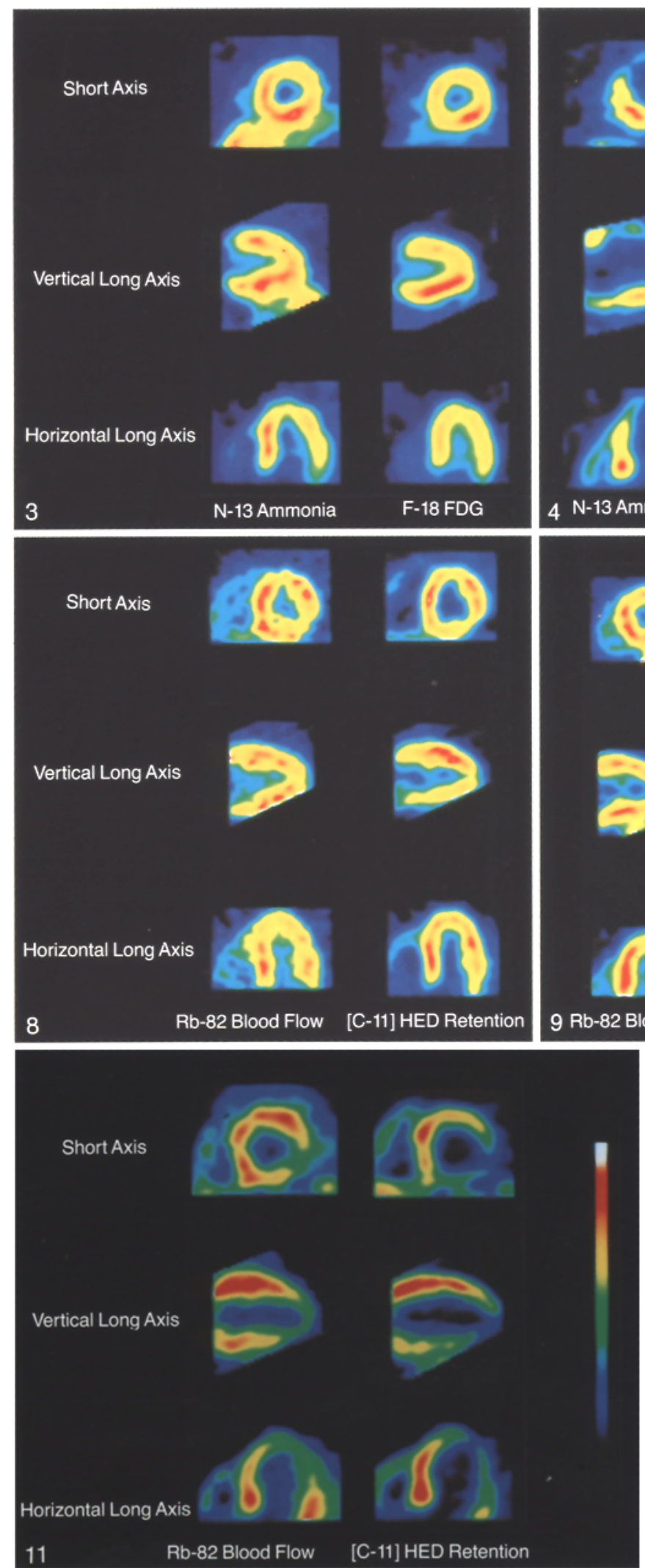

Fig. 3. Positron emission tomography (PET) study of myocardial blood flow and glucose utilization in normal heart. Selected short axis (above), vertical long axis (middle) and horizontal long axis (below) are presented following intravenous injection of nitrogen-13 ammonia (left panel) and ${ }^{18} \mathrm{~F}-\mathrm{FDG}$ (right panel)
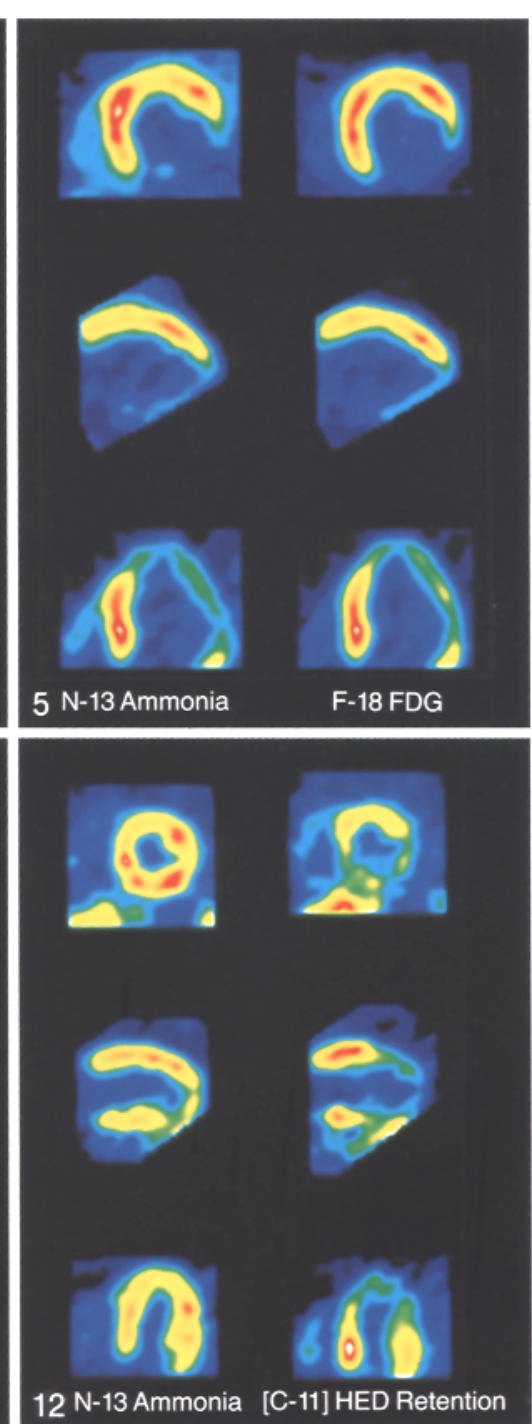

$[\mathrm{C}-11] \mathrm{HED}$
Retention

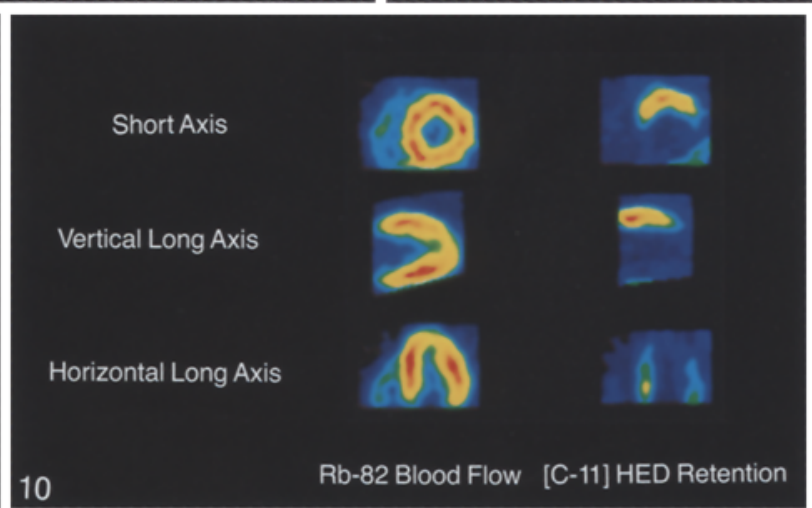

Fig. 4. PET myocardial viability study. Reduced resting perfusion as determined by ${ }^{13} \mathrm{~N}$-ammonia (left panel) in the anterolateral wall with relatively increased ${ }^{18} \mathrm{~F}$-FDG retention (right panel) in the same area of this patient with prior myocardial infarction suggest the presence of ischaemically jeopardized but viable myocardium in this territory. Short axis, above; vertical long-axis; middle, horizontal long axis, below

Fig. 5. PET myocardial viability study. Reduced resting perfusion (left panel) with matched reduced FDG retention (right panel) in the inferolateral wall of this patient with prior inferior myocardial infarction represents non-viable myocardium in this territory 
Assessment of tissue viability in stable coronary artery disease

The assessment of function, perfusion and coronary anatomy is an important part of the evaluation of patients with ischaemic heart disease. It has been well demonstrated that patients with ischaemic heart disease associated with left ventricular impaired function may benefit from revascularization (Alderman et al. 1983; Detre et al. 1981; European Coronary Surgery Study Group 1982; Freedman et al. 1984; Passamani et al. 1985). Since improvement of left ventricular function depends on the presence of residual tissue viability, the differentiation between ischaemically compromised and non-viable myocardium has become an important clinical question. Regional contractile dysfunction and reduced blood flow are frequently shared by infarcted and ischaemic tissue, complicating the identification of viable tissue. Thus, the use of metabolic tracers may represent a unique means to identify ischaemic myocardium with persistent metabolic activity which is expected to benefit from blood flow restoration.

Several animal studies have demonstrated enhanced ${ }^{18} \mathrm{~F}$-FDG uptake in viable, ischaemically injured myocardium (Kalff et al. 1989; Schwaiger 1986; Schwaiger et al. 1985). Based on these experimental data, ${ }^{18} \mathrm{~F}-\mathrm{FDG}$ has been tried in patients with coronary artery disease.

Fig. 8. PET images following intravenous injection of rubidium- 82 (left panel) and ${ }^{11} \mathrm{C}$-HED (right panel) in the normal heart. The images show a homogeneous distribution of HED throughout the left ventricle representing a homogeneous distribution of sympathetic nerve terminals throughout the left ventricle

Fig. 9. PET images in a patient with recent cardiac transplantation Blood flow images (left panel) indicate homogeneous perfusion throughout the left ventricle. Images obtained following intravenous injection of ${ }^{11} \mathrm{C}$-HED (right panel) show a marked reduction of tracer retention

Fig. 10. PET images in a patient 55 months after cardiac transplantation. Blood flow images (left panel) show a homogeneous perfusion throughout the left ventricle. Images obtained following intravenous injection of ${ }^{11} \mathrm{C}-\mathrm{HED}$ (right panel) show tracer retention in the anterobasal segment of the left ventricle which represents catecholamine uptake and storage in this territory

Fig. 11. PET images in a patient with recent myocardial infarction and thrombolytic therapy. Blood flow images (left panel) show a small perfusion abnormality in the inferolateral wall of the left ventricle. Images obtained following intravenous injection of ${ }^{11} \mathrm{C}$ HED show a larger area with marked reduction of tracer retention, suggesting injury of the sympathetic nerve terminals

Fig. 12. PET images in a patient with dilated cardiomyopathy. Blood flow images (left panel) show a homogeneous perfusion throughout the left ventricle. Images obtained following intravenous injection of ${ }^{11} \mathrm{C}$-HED (right panel) show a heterogeneous tracer retention throughout the left ventricle which represents a heterogeneous pattern of neuronal dysfunction
Marshall et al. (1983b) performed the first study involving patients with previous myocardial infarction. They demonstrated a high incidence of ${ }^{18} \mathrm{~F}-\mathrm{FDG}$ uptake in segments with reduced blood flow (Figs. 4, 5). Those myocardial segments correlated with the presence of postinfarction angina, the site of ischaemic electrocardiographic changes during ischaemia and the presence of severe coronary artery disease. This study has been followed by others correlating ${ }^{18}$ F-FDG uptake with conventional markers of myocardial viability such as $Q$ waves on the electrocardiogram (Brunken and Shelbert 1989; Brunken et al. 1986, 1987, 1989; Tamaki et al. 1988). Having demonstrated cell viability in patients with previous infarction, subsequent studies focused on the predictive value of persistent ${ }^{18} \mathrm{~F}-\mathrm{FDG}$ uptake in segments with low flow for functional recovery after revascularization. Tillisch et al. (1983) evaluated the functional recovery of hypokinetic segments with persistent uptake 6 weeks after surgical revascularization. They demonstrated that persistent ${ }^{18} \mathrm{~F}$-FDG uptake was $85 \%$ predictive for the recovery of contractility, while the absence of metabolic activity in segments with low flow was associated with a lack of contractile recovery. This observation was confirmed by others. Tamaki et al. (1989) showed contractility improvement in $78 \%$ of the segments with persistent ${ }^{18} \mathrm{~F}$-FDG uptake in comparison with only $22 \%$ of the segments without it. Table 1 summarizes the predictive value of PET criteria for tissue recovery following revascularization as defined by the investigations of several laboratories.

Thallium-201 scintigraphy has been most widely applied to detect myocardial viability in the clinical setting. It has been accepted that redistribution within a stressinduced ${ }^{201} \mathrm{Tl}$ defect represents tissue viability. However, more recent studies indicated that the presence of fixed ${ }^{201} \mathrm{Tl}$ defects may overestimate the scar tissue extent. Such investigations have shown that $30 \%-70 \%$ of segments with a fixed defect have a normalized ${ }^{201} \mathrm{Tl}$ uptake after surgical revascularization (Gibson et al. 1983; Liu et al. 1985). In addition, $30 \%-50 \%$ of myocardial segments with ${ }^{201} \mathrm{Tl}$-fixed defects demonstrate PET viability (Brunken and Schelbert 1989; Brunken et al. 1987; Tamaki et al. 1988). Recently, ${ }^{201} \mathrm{Tl}$ reinjection protocols have been introduced to improve the detection of viable tissue (Dilsizian et al. 1990; Kiat et al. 1988; Ohtani et al. 1990). However, further comparative studies with PET are required to identify the benefit of this new protocol for the detection of viable tissue. Resting ${ }^{201} \mathrm{Tl}$ scintigraphy with delayed imaging may provide the most accurate definition of tissue viability short of PET (Ritchie et al. 1979). On the other hand, PET has proven especially helpful at our institution in patients with severely reduced left ventricular function who were either considered for "high risk" surgical revascularization or heart transplantation. The excellent image quality and the specific metabolic information provided by PET has made this test an important part of the clinical decisionmaking process in these patients. 
Table 1. PET and thallium-201 SPET predictive values for recovery of contractile function following revascularization

\begin{tabular}{|c|c|c|c|c|}
\hline Technique & $n$ & $\begin{array}{l}\text { Viable tissue } \\
\text { (recovery) }\end{array}$ & $\begin{array}{l}\text { Non-viable tissue } \\
\text { (no recovery) }\end{array}$ & Reference \\
\hline \multicolumn{5}{|l|}{ PET } \\
\hline $\mathrm{FDG} / \mathrm{NH} 3$ & 17 & $35 / 41(85 \%)$ & $24 / 26(92 \%)$ & Tillisch et al. 1983 \\
\hline $\mathrm{FDG} / \mathrm{NH} 3$ & 22 & $18 / 23(78 \%)$ & $18 / 23(78 \%)$ & Tamaki et al. 1989 \\
\hline \multicolumn{5}{|l|}{ SPET } \\
\hline Reinjection ${ }^{201} \mathrm{Tl}$ & 24 & $10 / 14(71 \%)$ & $22 / 26(85 \%)$ & Ohtani et al. 1990 \\
\hline Reinjection ${ }^{201} \mathrm{Tl}$ & 20 & $13 / 15(87 \%)$ & $8 / 8(100 \%)$ & Dilsizian et al. 1990 \\
\hline Redistribution ${ }^{201} \mathrm{Tl}$ & 21 & $67 / 73(85 \%)$ & $34 / 112(28 \%)$ & Kiat et al. 1988 \\
\hline 24-h redistribution & 21 & $70 / 74(95 \%)$ & $30 / 48(63 \%)$ & Kiat et al. 1988 \\
\hline
\end{tabular}

FDG/NH3, Fluorine-18 fuorodeoxyglucose and nitrogen-13 ammonia; SPET, single photon emission tomography; Redistribution ${ }^{201} \mathrm{Tl}$, thallium redistribution imaging at $3-4 \mathrm{~h}$ after stress; Reinjec-

\section{Acute myocardial infarction}

PET has also been used in the acute phase of myocardial infarction (Czernin et al. 1990; Schwaiger et al. 1986). Metabolic imaging has demonstrated the impairment of the oxidative metabolism in the clinical infarct zone (Walsh et al. 1989). The absence of metabolic activity in the infarct area has been highly predictive of completed tissue necrosis and of no further functional recovery. However, persistent metabolism in the infarct territory revealed by ${ }^{18} \mathrm{~F}$-FDG uptake has been associated with a variable functional outcome (Schwaiger et al. 1986). The variability of functional recovery has been interpreted as the dynamic process of cellular death after the ischaemic insult or subsequent vessel reocclusion. Comparing coronary angiography and regional glucose metabolism, Schwaiger et al. (1987) have shown that, as compared with an area of infarction subtended by an occluded vessel, an area with persistent antegrade flow in the infarct vessel was characterized by enhanced ${ }^{18} \mathrm{~F}$ FDG uptake, confirming the beneficial effect on metabolism of residual blood flow in the infarcted territory. All these studies were performed before the era of thrombolytic therapy. It is now widely accepted that the initiation of thrombolytic therapy early after the onset of symptoms of myocardial infarction limits the size of the necrosis and improves survival (GISSI 1986; ISIS-2 1988). Therefore, any time-consuming PET imaging may not be warranted before the completion of thrombolytic treatment. However, several reports support the notion that PET may play a role in the evaluation of patients early after the myocardial insult (Hicks et al. 1990; Vanoverschelde et al. 1992). Due to myocardial stunning, it may be difficult to appreciate the success of the thrombolytic treatment based on regional wall motion. In addition, the persistence of significant stenosis in the infarct vessel has been frequently reported after successful thrombolysis (Topol et al. 1987). Therefore, PET may tion ${ }^{201} \mathrm{Tl}$, thallium imaging following reinjection of approximately $1 \mathrm{mCi}$ of ${ }^{201} \mathrm{Tl} 3-4 \mathrm{~h}$ after stress; $24 \mathrm{~h}$ redistribution, thallium redistribution imaging approximately $24 \mathrm{~h}$ after stress imaging

be helpful for the early detection of the amount of salvaged as well as jeopardized viable myocardium and could contribute to the selection of patients who could benefit from revascularization in the subacute period of their myocardial infarction (vom Dahl et al. 1991).

\section{Dilated cardiomyopathy}

The pathophysiology of dilated cardiomyopathy remains poorly understood. With a few exceptions (carnitine deficiency or nutritional deficiency related to alcohol consumption), there is no evidence that a metabolic abnormality is directly associated with this cardiac disease. So, contrary to ischaemic heart disease, we cannot rely on experimental data to guide metabolic imaging approaches for the diagnosis and staging of the myopathic process. Therefore, metabolic imaging only indirectly reflects the deterioration of overall left ventricular performance.

Without history or electrocardiographic signs of previous myocardial infarction, it may be difficult to differentiate ischaemic and non-ischaemic cardiomyopathy. Using PET with ${ }^{13} \mathrm{NH}_{3}$ and ${ }^{18} \mathrm{~F}-\mathrm{FDG}$, Mody-Vaghaiwalla et al. (1988) demonstrated the accuracy of cardiac imaging to differentiate ischaemic heart disease and idiopathic dilated cardiomyopathy. ${ }^{13} \mathrm{NH}_{3}$ and ${ }^{18} \mathrm{~F}$-FDG patterns were more homogeneous in patients with ischaemic than non-ischaemic cardiomyopathy. Geltman et al. (1983) also described similar distinct patterns of ${ }^{11} \mathrm{C}$-palmitate distribution between patients with previous myocardial infarction and those with nonischaemic cardiomyopathy.

Employing analysis of the ${ }^{11} \mathrm{C}$-palmitate kinetics, Schelbert et al. (1986) studied the free fatty acid metabolism in patients with severely impaired ventricular function. Following glucose oral loading, they showed that more than $40 \%$ of these patients had a paradoxical acce- 
lerated clearance of ${ }^{11} \mathrm{C}$-palmitate activity as compared with normals. The biochemical mechanism and the significance of this observation remain unclear and require further clinical investigations. More recently, the cardiac oxidative metabolism of patients with dilated cardiomyopathy has been assessed using ${ }^{11} \mathrm{C}$-acetate (Chan et al. 1990). Following correction for the loading conditions of the left ventricle, the oxygen consumption was found to be decreased in these patients. Experimental data in the canine model suggest that the cardiac performance of the impaired left ventricle may be non-invasively assessed by a combined use of ${ }^{11} \mathrm{C}$-acetate clearance and echocardiographically derived parameters of cardiac work efficiency (Wolpers et al. 1990). Such a measurement of myocardial efficiency may allow a noninvasive determination of therapeutic interventions by serial metabolic and echocardiographic studies.

\section{B. Evaluation of cardiac innervation}

The heart is characterized by its ability to respond quickly to changing body demands. This integrated function is achieved through the autonomic nervous system. Both sympathetic and parasympathetic nervous systems innervate the heart and regulate cardiac electrophysiological and hemodynamic adaptation to varying demands. The neurotransmitters of the sympathetic and parasympathetic nervous systems are noradrenaline and acetylcholine, respectively. The atria, the sinoatrial node and the atrioventricular node are regulated by both the sympathetic and parasympathetic nervous systems. However, the neuronal structure in the ventricular myocardium are primarily sympathetic nerve fibres. Based on the measurement of the tissue noradrenaline content, the heart displays a denser sympathetic fibre network in the right than in the left ventricle as well as in the base than in the apex of the ventricles (Angelakos 1965; Angelakos et al. 1969; Pierpont et al. 1985). Histology as well as electrophysiology studies suggest that the sympathetic nerves travel in the superficial subepicardium of the ventricles primarily following the coronary vessels (Randall and Ardell 1988). As they progress from base to apex, they gradually penetrate the myocardium and innervate the endocardium by plexus terminals. The sympathetic nerve terminals include vesicles which represent a storage pool for the neurotransmitter, enzymes and other proteins (Fig. 6). Upon nerve stimulation, noradrenaline is released by exocytosis in the synaptic cleft. The regulation of the adrenaline release is complex and is mediated by different presynaptic receptors (Francis 1988; Muscholl et al. 1979). Noradrenaline itself exerts a negative feed-back control by fixation on $\alpha_{2}$ presynaptic receptors (Langer 1980). The fate of the released noradrenaline is manifold. Only a small amount activates specific receptors on the surface of the myocytes, and a fraction present in the synaptic cleft diffuses in to the vascular space. The majority of the extraneuronal nor-

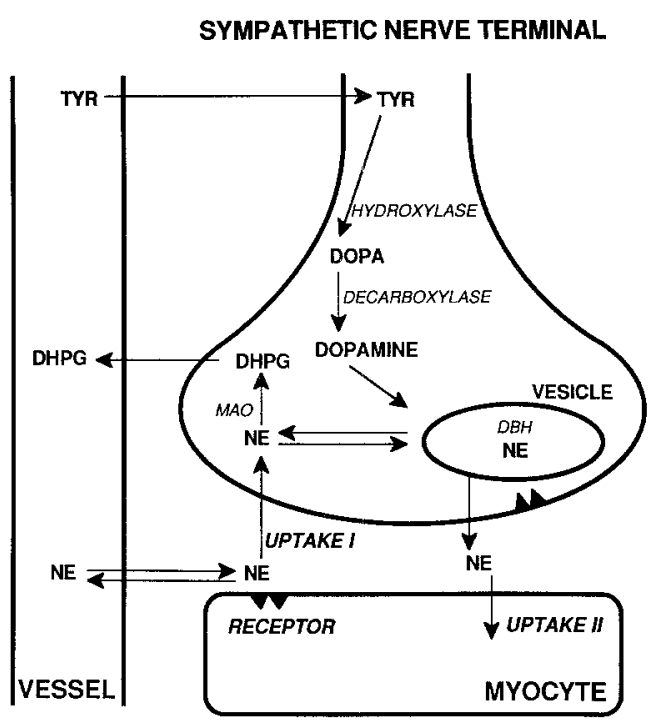

Fig. 6. Sympathetic nerve terminal and noradrenaline metabolism: $N E$, norepinephrine; $T Y R$, tyrosine; $D H P G$, dihydroxyphenolglycol; $D B H$, dopamine $\beta$-hydroxylase; $M A O$, monoamine oxidase

adrenaline is removed by the nerve terminal itself (Goldstein et al. 1988). This reuptake, called uptake-1, removes as much as $70 \%$ of the released noradrenaline and plays an important role in the regulation of the extraneuronal noradrenaline tissue concentrations ( $\mathrm{Ax}$ elrod 1960). Following reuptake into the nerve terminal, noradrenaline is concentrated again in the storage vesicles for subsequent release (Njus et al. 1986). Noradrenaline is metabolized by monoamine oxidase (MAO) in the neuronal cytosol and by catechol- $O$-methyl transferase (COMT) principally concentrated in non-neuronal tissue.

Contrary to the sympathetic nervous fibres, the sparse parasympathetic fibres travel along the ventricles in the subendocardium and subsequently penetrate upward to innervate the epicardium (Zipes and Inoue 1988). Acetylcholine, the parasympathetic neurotransmitter, is synthesized by the acetylation of choline. Choline enters the cytosol of the nerve terminals via the high-affinity choline uptake system (Ducis 1988) and is rapidly acetylated by choline acetyltransferase. Then acetylcholine is shuttled into the storage vesicles. The vesicular uptake system also presents a high specific affinity for acetylcholine (Zimmermann 1988). Upon nerve stimulation, acetylcholine is released, activates postsynaptic receptors and is rapidly hydrolyzed by the great quantities of acetylcholinesterase.

\section{PET radiopharmaceuticals for mapping presynaptic nerve terminals}

\section{Sympathetic neuron tracers}

${ }^{18}$ F-metaraminol (FMR) (Mislankar et al. 1988) and ${ }^{11} \mathrm{C}$-hydroxyephedrine (HED) (Rosenpire et al. 1990) 
<smiles>NCC(O)c1ccc(O)c(O)c1</smiles>

NOREPINEPHRINE (NE)

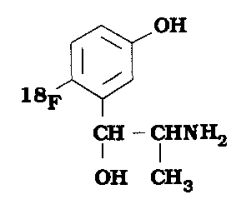

6-[18 ${ }^{18}$ FLUOROMETARAMIN OL (FMR)

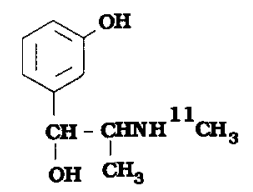

[11 C]META - HYDROXYEPHEDRINE (HED)

Fig. 7. Chemical structure of norepinephrine (NE) and catecholamine analogues, $6-{ }^{18} \mathrm{~F}$-fluorometaraminol (FMR) and ${ }^{11} \mathrm{C}$-metahydroxyephedrine (HED)

have been developed to characterize non-invasively the sympathetic nerve terminals of the heart using PET imaging (Fig. 7). FMR, a false neurotransmitter which is a close structural analogue of noradrenaline, has been chosen for its high affinity for uptake-1. As compared with noradrenaline, FMR is characterized by the presence of an $\alpha$-methyl group and the absence of a catechol group. This particular chemical structure protects FMR against metabolization by monoamine oxidase (MAO). Once in the neuronal cytoplasm, FMR is sequestered in the storage vesicles and, upon stimulation, is released with endogenous noradrenaline. However, the specific activity achievable by labelling metaraminol with fluorine-18 has been low. The mass of unlabelled FMR in projected clinical doses has been, thus, too close to pharmacological levels for safe use in humans. ${ }^{11} \mathrm{C}-\mathrm{HED}$, very similar to FMR, has been chosen as an alternate radiopharmaceutical for use in human studies and has been labelled with high specific activity. To verify the specificity of FMR (Wieland et al. 1990) and HED (Wieland et al., unpublished data) retention by sympathetic nerve terminals, the tracers have been injected into animals after pretreatment by desipramine (uptake-1 inhibitor) or reserpine (vesicle storage inhibitor). As compared with controls, desipramine as well as reserpine have dramatically decreased the tissue tracer retention. These data indicate that the tracer retention specifically reflects neuronal uptake and vesicular storage.

PET imaging techniques have been employed to evaluate both radiopharmaceuticals for non-invasive assessment of the distribution of sympathetic nerve terminals. Tracer kinetics have been studied in a chronic dog model with regional denervation of the heart through the epicardial application of phenol. Both the FMR and HED tissue concentrations as assessed by PET have been found to correlate linearly with the regional noradrenaline content of the myocardium (Wieland et al. 1990).

Parasympathetic neuron tracers

The synthesis of tracers for the parasympathetic neuron remains difficult. They must have a chemical structure that not only resists hydroxylation by acetylcholinesterase but also is recognized by the high specific transport and storage systems. Vesamicol (an analgesic compound) and its benzo-derivatives display a high affinity for the parasympathetic synaptic vesicles and may represent valuable tracers (Brittain et al. 1969; Rogers et al. 1989). However, further studies are needed to confirm the specificity of their retention in parasympathetic nerve terminals.

\section{PET agents for mapping postsynaptic receptors}

The ${ }^{11} \mathrm{C}$-labelled $\beta$-blockers were synthesized to trace the $\beta$-receptor distribution of the heart but have found limited use in PET imaging because of intense pulmonary uptake due to their lipophilicity. Early results with the hydrophilic compound ${ }^{11} \mathrm{C}-\mathrm{CGP} 12177$ are promising for the in vivo evaluation of myocardial $\beta$-receptors in animal (Delforge et al. 1991 b) and human studies (Merlet et al. 1991).

${ }^{11} \mathrm{C} \mathrm{N}$-methyl quinuclinidyl benzilate $\left({ }^{11} \mathrm{C}\right.$-methylQNB) (Delforge et al. 1991 a; Maziere et al. 1981) and ${ }^{11} \mathrm{C} \mathrm{N}$-methyl tropapyl benzilate $\left({ }^{11} \mathrm{C}\right.$-methyl-TRB) (Mulholland et al. 1988) represent potential tracers to delineate the muscarinic receptor distribution of the human heart. Animal and clinical studies have shown a high tracer uptake in the heart with little non-specific binding (Brown and Golstein 1986; Fields et al. 1978; Mulholland et al. 1989; Syrota et al. 1985).

\section{Clinical evaluation of sympathetic nerve terminals}

PET investigations of the human sympathetic nervous system at our institution have been limited to the use of ${ }^{11} \mathrm{C}$-HED. After ${ }^{11} \mathrm{C}$-HED administration, high quality images of the heart can be achieved (Schwaiger et al. 1990). The distribution of ${ }^{11} \mathrm{C}-\mathrm{HED}$ is homogeneous throughout the normal heart, reflecting the distribution of sympathetic fibres throughout the myocardium (Fig. 8). The study of patients soon after heart transplantation provided a unique model of cardiac denervation (Schwaiger et al. 1991). The ${ }^{11} \mathrm{C}-\mathrm{HED}$ myocardial content was homogeneous in these patients, but the tracer retention in the transplanted heart was reduced by $76 \%$ in comparison with the normal heart. These results confirmed the specificity of the tracer for neuronal structures.

Reinnervation of transplanted organs has been demonstrated in animals, but reinnervation of the human heart transplant has remained controversial. The study of patients with a remote heart transplantation $(3.5 \pm 1.3$ 
years) demonstrated an inhomogeneous pattern of ${ }^{11} \mathrm{C}$ HED cardiac retention. Higher tracer uptake in the basal region of the left ventricle was observed, providing the first direct evidence of cardiac reinnervation after transplantation in humans (Figs. 9, 10). The pattern of ${ }^{11} \mathrm{C}$ HED uptake suggests partial reinnervation along the anterior surface of the heart. Correlation with functional measures of the autonomic nervous system are needed to define the clinical significance of these scintigraphic findings.

Combined studies of perfusion and neuronal function using ${ }^{11} \mathrm{C}$-HED in patients with acute myocardial infarction have revealed a neuronal dysfunction of the ischaemically injured myocardium, confirming previous animal studies (Allman et al. 1991) (Fig. 11). Since the heterogeneity of sympathetic tone has been linked to dysrhythmia in patients with ischaemic heart disease, this imaging approach may provide information which may help to identify patients with a high risk for sudden death.

Abnormality of the sympathetic nervous system has also been described in patients with dilated cardiomyopathy. In these patients, an increase of the sympathetic tone involving high plasma noradrenaline levels reflects a physiological response to a decreased cardiac output. In vitro studies have demonstrated a decrease of the postsynaptic $\beta$-receptor density in patients with congestive heart failure which has been interpreted as $\beta$-receptor down-regulation resulting from noradrenaline overstimulation (Bristow et al. 1982; Fowler et al. 1986; Francis and Cohn 1986). Since the reuptake and storage of noradrenaline in the presynaptic nerve terminals is an important mechanism for regulating the extraneuronal noradrenaline content, the dysfunction of the nerve terminals may be an important pathophysiological mechanism in catecholamine overexposure of the postsynaptic receptor sites. Scintigraphy studies with ${ }^{11} \mathrm{C}$ HED in patients with failing hearts have shown a decrease of tracer retention in comparison with normal control patients (Schwaiger et al. 1990). The degree of abnormality varied regionally, indicating a heterogeneous pattern of neuronal dysfunction (Fig. 12). These PET data indicate an altered neuronal reuptake function in cardiomyopathy and, thus, support the notion of $\beta$ receptor down-regulation due to presynaptic dysfunction. This hypothesis is strengthened by recent clinical observations reporting beneficial effects of $\beta$-receptor blockade in patients with congestive heart failure (Waagstein et al. 1989). Thus, quantitative delineation of the sympathetic function by PET may aid in the selection of patients for therapy with $\beta$-receptor blockers and contribute to the better understanding of the abnormalities of sympathetic innervation in dilated cardiomyopathy.

\section{Conclusion}

PET provides a unique scientific tool to probe non-invasively the biochemistry and other tissue functions of the living heart. The current progress in both PET technology and tracer kinetics modelling now allow quantitative evaluation of regional physiologic processes such as blood flow, metabolic rates and neuronal function. In severe coronary artery disease, metabolic imaging with PET has proven to be clinically useful for the definition of tissue viability. This application represents the most commonly employed PET study in cardiac patients at our institution. In non-ischaemic heart disease, PET must still be considered experimental and requires further clinical validation. The recent development of neuronal tracers presents an opportunity to image the autonomic nervous system of the heart. The availability of short-lived radiopharmaceuticals allows the characterization of different aspects of neuronal function, such as presynaptic and postsynaptic tracer binding. The unique information provided by PET in neurocardiology will make this technique an attractive research tool for the delineation of neuronal abnormalities in various cardiovascular disease processes. However, at the present time, there are no clearly defined clinical applications of neuroimaging in cardiac patients.

We are confident that future PET research studies employing sophisticated, mathematical tracer modelling and the synthesis of new radiopharmaceuticals will contribute to a better understanding of cardiac metabolism and regulation of cardiac function by the autonomic nervous system.

\section{References}

Alderman EL, Fisher LD, Litwin P, Kaiser GC, Myers WO, Maynard C, Levine F, Schloss M (1983) Results of coronary artery surgery in patients with poor left ventricular function (CASS). Circulation 68:785-795

Allman K, Wolfe E, Sitomer J, Hutchins G, Wieland D, Schwaiger M (1991) C-11 hydroxyephedrine assessment of regional myocardial sympathetic neuronal function following acute myocardial infarction in man (abstract). J Nucl Med 32:1040

Angelakos ET (1965) Regional distribution of catecholamines in the dog heart. Circ Res 16:39-44

Angelakos ET, King MP, Millard RW (1969) Regional distribution of catecholamines in the heart of various species. Ann NY Acad Sci 156:219-240

Armbrecht JJ, Buxton DB, Brunken RC, Phelps ME, Schelbert HR (1989) Regional myocardial oxygen consumption determined noninvasively in humans with $\left[1-{ }^{11} \mathrm{C}\right]$ acetate and dynamic positron tomography. Circulation $80: 863-872$

Axelrod J (1960) The fate of adrenaline and noradrenaline. In: Vane J, Wolstenholme G, O'Connor M (eds) Adrenergic mechanisms. Little, Brown, Boston, pp 28-39

Bergmann SR (1989) Clinical applications of assessments of myocardial substrate utilization with positron emission tomography. Mol Cell Biochem 88:201-209

Bing RJ (1954) The metabolism of the heart. (Harvey Lecture Series, L) Academic Press, London, pp 27-70

Bing RJ (1965) Cardiac metabolism. Physiol Rev 45:171-213

Bristow MR, Ginsburg R, Minobe W, Cubiciotti RS, Sageman WS, Lurie KG, Billigham ME, Harrison DC, Stinton EB (1982) 
Decreased catecholamine sensitivity and $\beta$-adrenergic receptor density in failing human hearts. N Engl J Med 30:205-211

Brittain R, Levy G, Tyers M (1969) The neuromuscular blocking action of 2-(4-phenylpiperidono)cyclohexanol (AH5183). Eur J Pharmacol 8:93-99

Brown JH, Golstein D (1986) Analysis of cardiac muscarinic receptors recognized selectively by non quaternary but not by quaternary ligands. J Pharmacol Exp Ther 238:580-586

Brown MA, Marshall DR, Sobel BE, Bergmann SR (1987) Delineation of myocardial oxygen utilization with carbon-11-labeled acetate. Circulation 76:687-696

Brown MA, Myears DW, Bergmann SR (1988) Noninvasive assessment of canine myocardial oxidative metabolism with carbon11 acetate and positron emission tomography. J Am Coll Cardiol 12:1054-1063

Brown MA, Myears DW, Bergmann SR (1989) Validity of estimates of myocardial oxidative metabolism with carbon-11 acetate and positron emission tomography despite altered patterns of substrate utilization. J Nucl Med 30:187-193

Brunken RC, Schelbert HR (1989) Positron emission tomography in clinical cardiology. Cardiol Clin 7:607-629

Brunken RC, Tillisch JH, Schwaiger M, Child JS, Marshall RC, Mandelkern M, Phelps ME, Schelbert HR (1986) Regional perfusion, glucose metabolism, and wall motion in patients with chronic electrocardiographic $Q$ wave infarctions: evidence for persistence of viable tissue in some infarct regions by positron emission tomography. Circulation 73:951-963

Brunken RC, Schwaiger M, Grover-McKay M, Phelps ME, Tillisch JH, Schelbert HR (1987) Positron emission tomography detects tissue metabolic activity in myocardial segments with persistent thallium perfusion defects. J Am Coll Cardiol 10:557-567

Brunken RC, Kottou S, Nienaber CA, Schwaiger M, Ratib OM, Phelps ME, Schelbert HR (1989) PET detection of viable tissue in myocardial segments with persistent defects at T1-201 SPET. Radiology 172:65-73

Buck A, Wolpers G, Hutchins G, Savas V, Mangner T, Nguyen N, Schwaiger M (1991) Effect of carbon-11-acetate recirculation on estimates of myocardial oxygen consumption by PET. J Nucl Med 32:1950-1957

Buxton DB, Schwaiger M, Nguyen A, Phelps ME, Schelbert HR (1988) Radiolabeled acetate as a tracer of myocardial tricarboxylic acid cycle flux. Circ Res 63:628-634

Buxton DB, Nienaber CA, Luxen A, Ratib O, Hansen H, Phelps ME, Schelbert HR (1989) Noninvasive quantitation of regional myocardial oxygen consumption in vivo with [1-11C]acetate and dynamic positron emission tomography. Circulation 79:134-142

Chan SY, Warner-Stevenson L, Brunken RC, Krivokapich J, Phelps ME, Schelbert HR (1990) Myocardial oxygen consumption in patients with idiopathic dilated cardiomyopathy (abstract). J Nucl Med 31:773

Czernin J, Porenta G, Brunken RC, Chan SY, Kuhle W, Phelps ME, Schelbert HR (1990) Oxidative and glycolytic metabolic tissue characterization in patients with acute myocardial infarction using dynamic PET (abstract). J Nucl Med 31:774

Dahl J vom, Sitomer J, Schwaiger M (1991) Simultaneous assessment of flow reserve and myocardial viability with PET in patients after myocardial infarction (abstract). J Nucl Med 32:1013

Delforge J, Guludec D Le, Syrota A, Crouzel C, Merlet P (1991 a) In vivo quantification of myocardial muscarinic receptors in humans with PET. Circulation 84 [Supp1 II] : II-423
Delforge J, Syrota A, Lancon J-P, Nakajima K, Loch C, Janier M, Valloiss J-M, Cayla J, Crouzel C (1991 b) Cardiac betaadrenergic receptor density measured in vivo using PET, CGP 12177 and a new graphical method. J Nucl Med 32:739-748

Detre K, Peduzzi P, Murphy M, Hultgren H, Thomsen J, Oberman A, Takaro $\mathrm{T}$, and The Veterans Administration Cooperative Study Group for Surgery for Coronary Arterial Occlusive Disease (1981) Effect of bypass surgery on survival of patients in low- and high-risk subgroups delineated by the use of simple clinical variables. Circulation 63:1329-1338

Dilsizian V, Rocco TP, Freeman NM, Leon MB, Bonow RO (1990) Enhanced detection of ischemic but viable myocardium by the reinjection of thallium after stress-redistribution imaging. $\mathrm{N}$ Engl J Med 323:141-146

Ducis I (1988) The high-affinity choline uptake system. In: Whittaker VP (ed) The cholinergic synapse. Springer, Berlin Heidelberg New York, pp 409-445

European Coronary Surgery Study Group (1982) Long-term results of prospective randomized study of coronary artery bypass surgery in stable angina pectoris. Lancet II :1173-1180

Fields JZ, Roeske WR, Morkin E, Yamasura HI (1978) Cardiac muscarinic cholinergic receptors. Biochemical identification and characterization. J Biol Chem 253:3251-3258

Fowler MB, Laser JA, Hopkins AL, Minobe W, Bristow MR (1986) Assessment of the $\beta$-adrenergic receptor pathway in the intact failing human heart: progressive receptor down-regulation and subsensitivity to agonist response. Circulation $74: 1290-1302$

Fox KA, Abendschein DR, Ambos HD, Sobel BE, Bergmann SR (1985) Efflux of metabolized and nonmetabolized fatty acid from canine myocardium. Implications for quantifying myocardial metabolism tomographically. Circ Res 57:232-243

Francis GS (1988) Modulation of peripheral sympathetic nerve transmission. J Am Coll Cardiol 12:250-254

Francis GS, Cohn JN (1986) The autonomic nervous system in congestive heart failure. Ann Rev Med 37:235-247

Freedman AP, Walsh WF, Giles RW, Choy D, Newman DC, Horton DA, Wright JS, Murray IP (1984) Early and long term results of coronary bypass grafting with severely depressed left ventricular performance. Am J Cardiol 54:749-754

Gallagher BM, Folwer JS, Gutterson NI, MacGregor RR, Wan CN, Wolf AP (1978) Metabolic trapping as a principle of radiopharmaceutical design: some factors responsible for the bidistribution of [18F[2-deoxy-2-fluoro-D-glucose. J Nucl Med 19:1154-1161

Gambhir SS, Schwaiger M, Huang SC, Krivokapich J, Schelbert HR, Nienaber CA, Phelps ME (1989) Simple noninvasive quantification method for measuring myocardial glucose utilization in humans employing positron emission tomography and fluorine-18 deoxyglucose. J Nucl Med 30:359-566

Geltman EM, Smith JL, Beecher D, Ludbrook PA, Pogossian MM Ter, Sobel BE (1983) Altered regional myocardial metabolism in congestive cardiomyopathy detected by positron tomography. Am J Med 74:773-785

Gibson RS, Watson DD, Taylor GC, Crosby IK, Wellons H, Holt N, Beller G (1983) Prospective assessment of regional myocardial perfusion before and after coronary revascularization surgery by quantitative thallium-201 scintigraphy. J Am Coll Cardiol 1:804-815

Goldstein D, Brush J Jr, Eisenhofer G, Stull R, Esler M (1988) In vivo measurement of neuronal uptake of norepinephrine in the human heart. Circulation 78:41-48

Gropler RJ, Siegel BS, Lee KJ, Moerlein SM, Perry DJ, Bergmann SR, Geltman EB (1990) Nonuniformity in myocardial accumu- 
lation of fluorine-18-fluorodeoxyglucose in normal fasted humans. J Nucl Med 31:1749-1756

Gruppo Italiano per lo Studio della Streptochinasi nell' Infarto Miocardico (GISSI) (1986) Effectiveness of intravenous thrombolytic therapy in acute myocardial infarction. Lancet I:397401

Henes CG, Bergmann SR, Walsh MN, Sobel BE, Geltman EM (1989) Assessment of myocardial oxidative metabolic reserve with positron emission tomography and carbon-11 acetate. $J$ Nucl Med 30:1489-1499

Hicks RJ, Dick RJ, Molina E, Wolpers HG, Al-Aouar ZR, Schwaiger $M$ (1990) Assessment of myocardial viability early following infarction using PET-derived $\mathrm{C}-11$ acetate kinetics (abstract). Circulation 82 [Suppl III]:III 479

Hicks RJ, Herman WH, Kalff V, Molina E, Wolfe E, Hutchins GD, Schwaiger M (1991) Quantitative evaluation of regional substrate metabolism in the human heart by positron emission tomography. I Am Coll Cardiol 18:101-111

Huang SC, Williams BA, Barrio JR, Krivokapich J, Nissenson C. Hoffman EJ, Phelps ME (1987) Measurement of glucose and 2-deoxy-2-[18F]fluoro-D-glucose transport and phosphorylation rates in myocardium using dual-tracer kinetic experiments. FEBS Lett 216:128-132

ISIS-2 (Second International Study of Infarct Survival) Collaborative Group (1988) Randomised trial of intravenous streptokinase, oral aspirin, both, or neither among 17,187 cases of suspected acute myocardial infarction: ISIS-2. Lancet II: $349-360$

Kalff V, Gallagher KP, Nguyen N, McClanahan T, Schork A, Schwaiger $M(1989)$ Dissociation of glucose utilization and flow in canine myocardial ischemia (abstract). Circulation 80 [Suppl II] $:$ II 638

Kiat H, Berman DS, Maddahi J (1988) Late reversibility of tomographic myocardial thallium-201 defects: an accurate marker of myocardial viability. J Am Coll Cardiol 12:1456-1463

Langer S (1980) Presynaptic receptors and modulation of neurotransmission: pharmacological implications and therapeutic relevance. Trends Neurosci $3: 110-112$

Lear J (1986) Principles of single and multiple radionuclide autoradiography. In: Phelps M, Maziotta J, Shelbert $\mathrm{H}$ (eds) Raven Press, New York, pp 197-235

Liedtke AJ (1981) Alterations of carbohydrate and lipid metabolism in the acutely ischemic heart. Prog Cardiovasc Dis $23: 321$ 336

Liu P, Kiess MC, Okada RD, Block PC, Strauss HW, Pohost GM, Boucher CA (1985) The persistent defect on exercise thallium imaging and its fate after myocardial revascularization: does it represent scar or ischemia? Am Heart J 110:996-1001

Marshall RC, Huang SC, Nash WW, Phelps ME (1983a) Assessment of the $\left[{ }^{18} \mathrm{~F}\right]$ fluorodeoxyglucose kinetic model in calculations of myocardial glucose metabolism during ischemia. J Nucl Med 24:1060-1064

Marshall RC, Tillisch JH, Phelps ME, Huang SC, Carson R, Henze E, Schelbert HR (1983b) Identification and differentiation of resting myocardial ischemia in man with positron computed tomography, 18F-labeled fluorodeoxyglucose and N-13 ammonia. Circulation 67:766-778

Maziere M, Comar D, Godot J, Collard P, Cepeda C, Naquet $R$ (1981) In vivo characterization of myocardium muscarinic receptors by positron emission tomography. Life Sci $29: 2391$ 2397

Merlet P, Delforge J, Dubois Rande JL, Benvenuti C, Crouzel $C$, Valette H, Fournier D, Castaigne A, Syrota A (1991) Decreased $\beta$-adrenergic receptor concentration in idiopathic car- diomyopathy assessed by positron emission tomography (abstract). Circulation 84 [Suppl II]: II-1685

Mislankar SG, Gildersleeve DL, Wieland DM, Massin CC, Mulholland GK, Toorongian SA (1988) 6-[18F]Fluorometaraminol: a radiotracer for in vivo mapping of adrenergic nerves of the heart. J Med Chem 31:362-366

Mody-Vaghaiwalla F, Brunken R, Nienaber C, Stevenson L, Phelps $\mathrm{M}$, Schelbert H (1988) Characterization of dilated and ischemic cardiomyopathy utilizing visual and circumferential profile analysis with PET (abstract). J Nucl Med 29:818

Mulholland G, Schwaiger M, Sherman P, Jewett D, Otto C (1988) New positron labeled quaternized muscarinic ligand as potential PET imaging agent (abstract). Circulation 67:597

Mulholland GK, Schwaiger M, Otto CA, Sherman PS, Jewett DM (1989) Synthesis and animal studies of C-11 tropapyl benzilate methiodide (MTRB). A promising ligand for muscarinic receptors (abstract) J Nucl Med 30:930

Muscholl E, Ritzel H, Rossler K (1979) Presynaptic muscarinic control of neuronal adrenaline release. In: Langer S, Stark $\mathrm{K}$, Dubocovich M (eds) Presynaptic receptors. Pergamon, Oxford, pp 287-291

Neely JR, Morgan HE (1974) Relationship between carbohydrate and lipid metabolism and the energy balance of heart muscle. Ann Rev Physiol 36:413-459

Njus D, Kelley P, Harnadek $G$ (1986) Bioenergetics of secretory vesicles. Biochim Biophys Acta 853:237-265

Ohtani H, Tamaki N, Yonekura X (1990) Value of thallium-201 reinjection after delayed SPET imaging for predicting reversible ischemia after coronary artery bypass grafting. Am J Cardiol $66: 394-399$

Opie LH, Owen P, Lubbe W (1975) Estimated glycolytic flux in infarcting heart. Recent Adv Stud Cardiac Struct Metab 7:249255

Passamani E, Davis KB, Gillepsie MJ, Killip T, and the principal investigators and their associates (1985) A randomized trial of coronary artery bypass surgery survival of patients with low ejection fraction. N Engl J Med 312:1665-1671

Phelps ME, Huang SC, Hoffman EJ, Selin C, Sokoloff L, Kuhl DE (1979) Tomographic measurement of local glucose metabolic rate in humans with (F-18)2-fluoro-2-deoxy-D-glucose: validation of method. Ann Neurol 6:371-388

Pierpont GL, DeMaster EG, Reynolds S, Peterson J, Cohn JN (1985) Ventricular myocardial catecholamines in primates. J Lab Clin Med 106:205-210

Randall W, Ardell J (1988) Functional anatomy of the cardiac efferent innervation. In: Kulbertus HE, Franck G (eds) Neurocardiology. Futura Publishing, New York, pp 3-24

Ratib O, Phelps ME, Huang SC, Henze E, Selin CE, Schelbert HR (1982) Positron tomography with deoxyglucose for estimating local myocardial glucose metabolism. J Nucl Mei $23: 577$ 586

Ritchie JL, Albro PC, Caldwell JH, Trobaugh GB, Hamilton GW (1979) Thalliwm-201 myocardial imaging: a comparison of redistribution and rest images. I Nucl Med 20:477-483

Rogers GA, Parsons SM, Anderson DC, Nilsson LM, Bahr BA, Korneich WD, Kaufman R, Jacobs RS, Kirtman B (1989) Synthesis, in vitro acetylcholine-storage-blocking activities, and biological properties of derivatives and analogues of trans-2-(4phenylpiperidono)cyclohexanol (vesamicol). I Chem 32:1217 1230

Rosenpire KC, Kaka MS, Van Dort M, Jewett DM, Gildersleeve DL, Schwaiger M, Wieland DM (1990) Synthesis and preliminary evaluation of [11C]metahydroxyephedrine: a false neu- 
rotransmitter agent for heart neuronal imaging. J Nucl Med $31: 163-167$

Schelbert HR, Henze E, Schon HR, Keen R, Hansen H, Selin C, Huang S-C, Barrio JR, Phelps ME (1983a) C-11 labelled palmitic acid for the non-invasive evaluation of regional myocardial fatty acid metabolism with positron computed tomography. III. In vivo demonstration of the effects of substrate availability on myocardial metabolism. Am Heart J 105:492-504

Schelbert HR, Henze E, Schön H, Najafi A, Hansen H, Huang S, Barrio J, Phelps M (1983 b) C-11 palmitic acid for the noninvasive evaluation of regional myocardial fatty metabolism with positron computed tomography. IV. In vivo demonstration of impaired fatty acid oxidation in acute myocardial ischemia. Am Heart J 106:736-750

Schelbert HR, Henze E, Sochor H, Grossman RG, Huang SC, Barrio JR, Schwaiger M, Phelps ME (1986) Effects of substrate availability on myocardial $\mathrm{C}-11$ palmitate kinetics by positron emission tomography in normal subjects and patients with ventricular dysfunction. Am Heart J 111:1055-1064

Schön H, Shelbert HR, Najafi A, Hansen H, Robinson G, Huang S-C, Barrio JR, Phelps ME (1982) C-11 labelled palmitic acid for the non-invasive evaluation of regional myocardial fatty acid metabolism with positron computed tomography. II. Kim netics of $\mathrm{C}-11$ palmitic acid in acutely ischemic myocardium. Am Heart I 103:548-561

Schwaiger M (1986) Time course of metabolic findings in coronary occlusion and reperfusion and their role for assessing myocardial salvage. Eur J Nucl Med 12:S54-S58

Schwaiger M, Schelbert HR, Ellison D, Hansen H, Yeatman L, Vinten Johansen J, Selin C, Barrio J, Phelps ME (1985) Sustained regional abnormalities in cardiac metabolism after transient ischemia in the chronic dog model. J Am Coll Cardiol $6: 336-347$

Schwaiger M, Brunken R, Grover MM, Krivokapich J, Child J, Tillisch JH, Phelps ME, Schelbert HR (1986) Regional myocardial metabolism in patients with acute myocardial infarction assessed by positron emission tomography. $\mathrm{J}$ Am Coll Cardiol $8: 800-808$

Schwaiger M, Brunken RC, Krivokapich J, Child JS, Tillisch JH, Phelps ME, Schelbert HR (1987) Beneficial effect of residual anterograde flow on tissue viability as assessed by positron emission tomography in patients with myocardial infarction. Eur Heart J 8:981-988

Schwaiger M, Hutchins G, Rosenspire K, Haka M, Wieland D (1990a) Quantitative evaluation of the sympathetic nervous sys* tem by PET in patients with cardiomyopathy (abstract). $\mathrm{J}$ Nucl Med 31:792

Schwaiger M, Kalff V, Rosenspire K, Haka MS, Molina E, Hutchins GD, Deeb M, Wolfe E Jr, Wieland DM (1990b) The noninvasive evaluation of the sympathetic nervous system in the human heart by PET. Circulation $82: 457-464$

Schwaiger M, Hutchins GD, Kalff V, Molina E, Rosenspire K, Haka MS, Malette S, Deeb GM, Abrams GD, Wieland DM (1991) Evidence of regional catecholamine uptake and storage sites in the transplanted human heart by positron emission tomography. J Clin Invest 87:1681-1690

Sobel BE, Weiss E, Welch M, Siegel B, Ter-Pogossian M (1977) Detection of remote myocardial infarction in patients with positron emission transaxial tomography and intravenous $\mathrm{C}-11$ palmitate. Circulation 55:853-857
Sokoloff L, Reivich M, Kennedy C, Rosiers MH Des, Patlak CS, Pettigrew KD, Sakurada O, Shinohara M (1977) The (14C) deoxyglucose method for the measurement of local cerebral glucose utilization: theory, procedure and normal values in the conscious and anesthetized albino rat. J Neurochem 28:897916

Syrota A, Comar D, Paillotin G, Davy JM, Aumont M-C, Stulzaft O, Maziere B (1985) Muscarinic cholinergic receptor in the hum man heart evidenced under physiological conditions by positron emission tomography. Proc Natl Acad Sci USA 82:584-588

Tamaki N, Yonekura Y, Yamashita K, Senda M, Saji H, Hashimoto T, Fudo T, Kambara H, Kawai C, Ban T, Konishi J (1988) Relation of left ventricular perfusion and wall motion with metabolic activity in persistent defects on thallium-201 tomography in healed myocardial infarction. Am J Cardiol 62:202-208

Tamaki N, Yonekura $Y$, Yamashita K. Saji H, Magata Y, Senda M, Konishi Y, Hirata K, Ban T, Konishi J (1989) Positron emission tomography using fluorine-18 deoxyglucose in evaluation of coronary artery bypass grafting. Am J Cardiol 64:860 865

Tillisch J, Brunken R, Marshall R, Schwaiger M, Mandelkern M, Phelps M, Schelbert H (1983) Reversibility of cardiac wallmotion abnormalities predicted by positron tomography. $N$ Engl J Med 314:884-888

Topol EJ, O'Neill WW, Langburd AB, Walton JA, Bourdillon PDV, Bates ER, Grines CL, Schork AM, Kline E, Pitt B (1987) A randomized, placebo-controlled trial of intravenous recombinant tissue-type plasminogen activator and emergency coronary angioplasty in patients with acute myocardial infarction. Circulation $75: 420-428$

Vanoverschelde J-LJ, Melin JA, Bol A, Vanbutsele R, Cogneau M, Labar D, Robert A, Michel C, Wijns W (1992) Regional oxidative metabolism in patients recovery from reperfused anterior myocardial infarction. Relation to regional blood flow and glucose uptake. Circulation 85:9-21

Waagstein $\mathrm{F}$, Caidahl $\mathrm{K}$, Wallentin I, Berg $\mathrm{C}-\mathrm{H}$, Hjalmarson A (1989) Long-term $\beta$-blockade in dilated cardiomyopathy: effects of short- and long-term metoprolol treatment followed by withdrawal and readministration of metoprolol. Circulation $80: 551-563$

Walsh MN, Geltman EM, Brown MA, Henes CG, Weinheimer CJ, Sobel BE, Bergmann SR (1989) Noninvasive estimation of regional myocardial oxygen consumption by positron emis" sion tomography with carbon-11 acetate in patients with myocardial infarction. J Nucl Med 30:1798-1808

Wieland DM, Rosenpire KC, Hutchins GD, Van Dort ME, Rothley JM, Mislankar SG, Lee HT, Gildersleeve DL, Sherman PS, Schwaiger M (1990) Neuronal mapping of the heart with 6-[F-18]fluorometaraminol. J Med Chem 33:956-964

Wolpers $H G$, Nguyen N, Buck A, Mangner TJ, Schwaiger M (1990) Relationship of C-11 acetate kinetics and hemodynamic performance in the canine heart (abstract). J Nucl Med 31:785

Zimmermann H (1988) Cholinergic synaptic vesicles. In: Whittaker VP (ed) The cholinergic synapse. Springer, Berlin Heidelberg New York, pp 350-382

Zipes DP, Inoue H (1988) Autonomic neural control of cardiac excitable properties. In: Kulbertus HE, Franck G (eds) Neurocardiology. Futura Publishing, New York, pp 787-796 